\title{
Economic and Financial Implications of Structural Reforms in the Economy of the Republic of Serbia
}

\author{
Edvard Jakopin ${ }^{1}$, Aleksandar Gracanac ${ }^{2}$, Jugoslav Anicic ${ }^{1}$ \\ ${ }^{1}$ Faculty of Economics and Finance, Union - Nikola Tesla University, Belgrade, Republic of Serbia \\ ${ }^{2}$ Faculty of Entrepreneurial Business and Real Estate Management, Union - Nikola Tesla University, Belgrade, Republic of Serbia
}

Email address:

edvard.jakopin@stat.gov.rs (E. Jakopin), agracanac@unionnikolatesla.edu.rs (A. Gracanac), janicic@unionnikolatesla.edu.rs (J. Anicic)

\section{To cite this article:}

Edvard Jakopin, Aleksandar Gracanac, Jugoslav Anicic. Economic and Financial Implications of Structural Reforms in the Economy of the Republic of Serbia. International Journal of Business and Economics Research. Vol. 10, No. 5, 2021, pp. 162-170.

doi: $10.11648 /$ j.ijber.20211005.11

Received: July 2, 2021; Accepted: September 14, 2021; Published: October 12, 2021

\begin{abstract}
Economic and financial performance of the economy in the boom period 2015-2019. are significantly improved. The average economic growth in Serbia of 3.5\% was higher than the average growth in the countries of the region. The key contribution to economic growth was made by investments, and to a lesser extent by the growth of personal consumption. The implemented structural reforms have had a positive impact on basic macroeconomic aggregates and productivity growth. The effects of the implemented fiscal consolidation in the economy of the Republic of Serbia have contributed to the continuous, from year to year, improvement of the macroeconomic and economic balance of the economy, although it should be noted that in 2019 there were signals of slowing down the trend. The fiscal deficit has been balanced since 2017, but the current account deficit remains acute. The trend of balanced public finances and reduction of public and external debt was disrupted in 2020 due to the pandemic caused by COVID-19. Due to the huge transition gap and peripheral economic status of the entire SEE area, despite the global situation, the implemented structural reforms did not proceed at the desired pace, especially in the segment of solving the problems of large state losers and economic and financial restructuring of public enterprises at all levels. Although the entrepreneurial sector has improved its performance, a number of institutional problems affecting the business environment remain. The structural analysis of the economy showed a continuation of the trend of strengthening the GVA of the service sector, repositioning of key sectors, as well as the trend of strengthening the influence of foreign private companies, which showed better business performance than domestic private companies. Structural reform activities in the coming period should primarily be directed towards creating the most stimulating environment for the development of domestic entrepreneurship and the growth of capital investments.
\end{abstract}

Keywords: Economic Growth in SEE Countries, Competitiveness and Structural Reforms, Sectoral and Property Changes

\section{Introduction}

The consequences of the global recession caused by the COVID-19 pandemic, which is the largest in terms of its negative effects since World War II [7], will mostly affect the performance of human capital and the slowdown of structural reforms in the economy 2020 [5].

The analytical perspective in the paper is focused on the key structural economic and financial performance in the economy of the Republic in the period 2015-2019. The aim of this paper is to consider the economic and financial implications of structural reforms and point out to economic policy makers the need for faster implementation of structural reforms in those areas of the economy that burden the economy, slow economic growth and reduce international competitiveness.

The initial hypotheses in the paper refer to the testing of structural performance in the function of economic growth, ie they are determined by the following assumptions:

1. Have the economic and financial performance of structural changes yielded positive results and contributed to faster economic growth and macroeconomic stability?

2. Are the economic and financial performance of foreign 
private enterprises more efficient than those under majority domestic ownership?

From the methodological point of view, the paper is based on the structural, qualitative and dynamic analysis of key indicators of economic and financial analysis of companies in the Republic of Serbia in the period 2015-2019. The paper consists of three interrelated units: the first is based on a comparative analysis of economic growth, competitiveness and reform progress of the countries in the region; the second is the macroeconomic and economic balance sheet, while the third part is focused on the basic results of the research of the complex structural analysis of the Serbian economy.

\section{Economic Growth, Competitiveness and Structural Reforms: A Comparative Analysis}

\subsection{Economic Growth in the Countries of the Region in the Period of Economic Boom}

Global economic trends affected the strong economic growth in the period 2015-2018, but in 2019 the first signals of a significant slowdown in economic growth appeared $(2.9 \%$ - the lowest growth rate since the global financial crisis). Of the four largest economies (USA, EU, China and Japan), the economies of the Eurozone and the USA weakened the most. The largest growth in the economy in that period was achieved by China (30\%) and India (37\%), which significantly increased their share in world GDP. Indications of recession and slowdown in economic activity in 2019 were most pronounced in emerging markets and economies in development, including Brazil, China, India, Mexico and Russia. The key reasons for the slowdown in growth in 2019 lie in: the slowdown in industrial production due to weaker external demand (including China); the growing global consequences of trade tensions and increased uncertainty about trust and investment; and a noticeable slowdown in global car production, which was especially significant for Germany. The world's largest economies accounted for $72.8 \%$ of total GDP in 2019 (US 24.4\% EU 21\%, China $16.3 \%$ and Japan 5.8\%). India also joined the Big Four with a share of $3.3 \%$ of world GDP, while the economy of the Russian Federation accounted for 1.9\% [15].

The largest economies of the EU, Germany, France, Great Britain (until 2020), Italy and Spain, accounted for $70 \%$ of EU GDP in 2019. Economic growth in the EU and the Eurozone recorded an average growth of over 2\%, until 2019 (Except Italy and France), when growth slowed.

All countries in our region are in the period 2015-2019. had average economic growth rates above 3\%, except for Croatia, which had a slightly lower rate. Romania recorded the highest growth rates (on average about 5\% per year). However, almost all economies see a slowdown in growth in 2019. Serbia maintained high GDP growth (4.2\%).

Table 1. GDP growth rates of neighboring countries, in $\%$.

\begin{tabular}{|c|c|c|c|c|c|c|c|}
\hline & \multirow{2}{*}{2015} & \multirow{2}{*}{2016} & \multirow{2}{*}{2017} & \multirow{2}{*}{2018} & \multirow{2}{*}{2019} & \multicolumn{2}{|l|}{2019} \\
\hline & & & & & & Rates & Bill. EUR \\
\hline Albania & 2.2 & 3.3 & 3.8 & 4.1 & 2.2 & 2.2 & 13.6 \\
\hline Bosnia & 3.1 & 3.1 & 3.2 & 3.7 & 2.6 & 2.6 & 17.9 \\
\hline Bulgaria & 4.0 & 3.8 & 3.5 & 3.1 & 3.4 & 3.4 & 60.7 \\
\hline Hungary & 3.8 & 2.2 & 4.3 & 5.1 & 4.9 & 4.9 & 143.8 \\
\hline Romania & 3.9 & 4.8 & 7.1 & 4.4 & 4.1 & 4.1 & 223.3 \\
\hline Northern Macedonia & 3.9 & 2.8 & 0.2 & 2.7 & 3.6 & 3.6 & 11.3 \\
\hline Croatia & 2.4 & 3.5 & 3.1 & 2.7 & 2.9 & 2.9 & 54 \\
\hline Montenegro & 3.4 & 2.9 & 4.7 & 5.1 & 3.6 & 3.6 & 4.9 \\
\hline
\end{tabular}

Source: Eurostat, EC European Economic Forecast Spring 2020, Summer 2020 (Interim) [3].

\subsection{International Competitiveness of the Serbian Economy and Structural Reforms}

Global economic systems, in which transnational companies, which control most of the manufacturing, trade and financial markets, play a leading role, leave very little room for small economies, especially in their efforts to improve their social and environmental performance. Bearing in mind that the entire SEE area, according to all representative economic indicators, is located on the economic periphery of Europe, the speed, commitment and capacity of the state in implementing structural reforms are the primary precondition for economic catching up and strengthening economic competitiveness.

The economies of all SEE countries are adapting to the process of globalization, increasing market competition, and high demands of competition. The transition experience of Central and Eastern European economies has shown that structural changes in the economy are the driver of strengthening macroeconomic performance and ensuring strong, sustainable and balanced growth [6] on the use of modern technology and economies of scale (primarily electrical industry, precision equipment industry, production of motor vehicles), while on the other hand, the largest decline occurred in labor-intensive industries (food, textile, wood industry).

The most competitive economy in the world in 2019 (with a score of 84.8), in the competition of 141 countries, is Singapore, which surpassed the United States, followed by Hong Kong SAR (3rd place), the Netherlands (4th) and Switzerland (5th). Of the G20 economies in the top 10 are the 
US (2nd place), Japan (6th), Germany (7th) and the UK (9th), while Argentina (83rd) is the lowest ranked from this group.

Due to the reform backlog in certain areas, the Serbian economy, according to the Global Competitiveness Index (GCI), fell by 7 places in 2019 compared to 2018 and is ranked 72nd in the world (out of 141 countries). Of the transition countries in the region, the economies of Slovenia (35), Hungary (47), Bulgaria (49), Romania (51) and Croatia (65) are ahead of Serbia. The most problematic of the mentioned 12 pillars of competitiveness are: institutions, ICT application, financial market development, health and market size.

Table 2. Global Competitiveness Index (GCI) 2019 for countries in the region.

\begin{tabular}{|c|c|c|c|c|c|c|c|c|c|}
\hline \multirow{2}{*}{ Pokazatelji } & \multirow{2}{*}{ ALB } & \multirow{2}{*}{ BUL } & \multirow{2}{*}{ HUN } & \multirow{2}{*}{ ROM } & \multirow{2}{*}{ SLO } & \multirow{2}{*}{ CRO } & \multicolumn{3}{|c|}{ SERBIA } \\
\hline & & & & & & & Rang & Value & Distance from the leader by the value \\
\hline GCI & 81 & 49 & 47 & 51 & 35 & 63 & 72 & 60.9 & 24 \\
\hline \multicolumn{10}{|l|}{ Subindex: Supporting Environment } \\
\hline 1. pillar: Institutions (20) indikatora) & 76 & 57 & 63 & 52 & 33 & 77 & 75 & 52.5 & 29 \\
\hline 2. pillar: Infrastructure (12) & 98 & 56 & 27 & 55 & 33 & 32 & 51 & 73.8 & 22 \\
\hline 3. pillar: Application IKT (5) & 75 & 30 & 54 & 32 & 40 & 60 & 77 & 52.6 & 40 \\
\hline 4. pillar: Makroeconomic stability (2) & 104 & 43 & 43 & 56 & 1 & 43 & 64 & 75.0 & 25 \\
\hline \multicolumn{10}{|l|}{ Subindex: HUMAN CAPITAL } \\
\hline 5. pillar: Health Protection (1) & 46 & 81 & 70 & 83 & 36 & 47 & 76 & 79.0 & 21 \\
\hline \multicolumn{10}{|l|}{ Subindex: MARKET } \\
\hline 7. pillar: Goods Market (8) & 75 & 63 & 91 & 64 & 30 & 86 & 73 & 54.6 & 27 \\
\hline 9. pillar: Financial Market (9) & 102 & 73 & 66 & 86 & 61 & 63 & 82 & 57.4 & 34 \\
\hline 10. pillar: Market Volume (2) & 111 & 64 & 48 & 41 & 82 & 78 & 74 & 51.8 & 48 \\
\hline
\end{tabular}

Source: WEF - The Global Competitiveness Report 2019 [14].

Structural reforms of the regulatory framework for business conditions are an extremely important factor in investment activities and attracting FDI. Serbia has made significant progress in this segment during the economic recovery period. The World Bank's Doing Business 2020 composite index ranks Serbia 44th (out of 190 countries). Serbia continues to record the most unfavorable rank in the area of obtaining electricity connections (94th position), obtaining loans (down from 60th to 67th), while the biggest decline in Serbia was registered in the field of starting a business (down 33 positions). In general, in relation to the countries of the region, Serbia is ranked ahead of Bosnia and Herzegovina (90th place), Albania (82nd), Romania (55th), Hungary (52nd), Croatia (51st) and Montenegro (50th), while Slovenia (37th) and Northern Macedonia (17th) are better placed.

Table 3. Ease of doing business - the most critical factors 2020.

\begin{tabular}{llllll}
\hline $\begin{array}{l}\text { Ease of doing } \\
\text { business }\end{array}$ & $\begin{array}{l}\text { Ease of doing } \\
\text { business }\end{array}$ & $\begin{array}{l}\text { Ease of doing } \\
\text { business }\end{array}$ & $\begin{array}{l}\text { Ease of doing } \\
\text { business }\end{array}$ & $\begin{array}{l}\text { Ease of doing } \\
\text { business }\end{array}$ & $\begin{array}{l}\text { Ease of doing } \\
\text { business }\end{array}$ \\
\hline 44 & 73 & 85 & 58 & 94 & 67 \\
\hline
\end{tabular}

Source: Doing Business Report 2020 [16].

Over the past three decades, the annual transition reports of the European Bank for Reconstruction and Development (EBRD) have provided the highest quality information to review the transitional reform period. In addition to a comparative analysis of the extent and quality of reforms undertaken, the EBRD transition indicators included an annual assessment of progress in transition at the sectoral level, pointed out basic constraints, pointed out the importance of transition to an open market economy and promoted entrepreneurship and privatization. In the recession period 2010-2014, Serbia did not make any reform progress. According to traditional EBRD indicators, Serbia lags the most in the area of privatization of large systems, management and restructuring of companies and implementation of competition policy [2].

The toolkit for monitoring the progress of reform processes has evolved over time, the original set of EBRD transition indicators has been supplemented by a series of nuanced sectoral indicators. The methodological concept of measuring the sustainability of economic growth was improved in 2017, emphasizing six key dimensions of reforms: (1) competitiveness, (2) good governance, (3) environmental orientation ("green" economy), (4) inclusiveness, (5) resilience, and (6) integration (both internally and with neighboring markets and with the global economy). In relation to the average transition assessment for 2019 (5.78), Serbia lags the most in the area of competitiveness (5.36), good governance (5.52), while in relation to the transition EU member states, it lags behind in all reform areas. The biggest reform challenges for SEE transition countries are environmental problems, inclusion (young people have insufficient access to work, migration flows) and resilience of financial sectors. 
Table 4. Reform progress in transition countries - EBRD indicators 2019.

\begin{tabular}{|c|c|c|c|c|c|c|c|}
\hline & Competitiveness & Management & Green Economy & Inclusion & Resistance & Integration & Average \\
\hline EU Members & 6.33 & 6.21 & 6.47 & 6.53 & 7.46 & 6.86 & 6.64 \\
\hline Croatia & 5.64 & 5.97 & 6.38 & 6.39 & 7.47 & 6.54 & 6.40 \\
\hline Bulgaria & 5.71 & 5.79 & 6.04 & 6.24 & 6.91 & 6.85 & 6.26 \\
\hline Hungary & 6.36 & 6.01 & 6.27 & 6.65 & 7.15 & 6.84 & 6.55 \\
\hline Romania & 6.01 & 6.04 & 6.14 & 5.74 & 7.11 & 6.75 & 6.30 \\
\hline Slovakia & 6.76 & 6.21 & 6.87 & 6.54 & 7.97 & 7.10 & 6.91 \\
\hline Slovenia & 7.09 & 6.65 & 7.08 & 7.35 & 7.73 & 7.14 & 7.17 \\
\hline Albania & 5.14 & 5.11 & 4.49 & 5.31 & 5.22 & 5.66 & 5.16 \\
\hline Montenegro & 5.44 & 6.11 & 5.41 & 5.98 & 6.44 & 6.15 & 5.92 \\
\hline Northern Macedonia & 6.02 & 5.57 & 5.16 & 5.90 & 5.93 & 5.75 & 5.72 \\
\hline Turkey & 5.42 & 6.18 & 5.28 & 5.01 & 7.02 & 5.70 & 5.77 \\
\hline Serbia & 5.36 & 5.52 & 5.79 & 6.16 & 5.86 & 5.99 & 5.78 \\
\hline Bosnia & 4.68 & 4.53 & 5.20 & 5.48 & 5.91 & 5.08 & 5.15 \\
\hline
\end{tabular}

Source: EBRD Transition report 2019-2020.

Improving reforms in the management of public enterprises and corporate governance would bring an additional $1 \%$ of economic growth per year. In addition, economic growth can only be achieved if it is inclusive, in terms of greater involvement of women, young talent, etc., as well as strengthening gender equality in the workplace. Obstacles facing Serbia include an inadequate educational structure of the workforce and a lack of work competencies.

\subsection{Institutional Reforms and Economic Growth}

Progress in all of the above relevant reform areas depends primarily on institutional reforms. The focus of transitional institutional reforms is on monitoring reforms in six key areas: (1) Freedom of speech and accountability (electoral participation, freedom of expression and media); (2) Political stability and the absence of terrorism; (3) Efficiency of government (quality of public services, civil service and the degree of their independence from political pressures, etc.); (4) Quality of regulation (promotion and development of the private sector), (5) Rule of law; and (6) Control of corruption (the extent to which public authority is used for private gain, the degree of abuse of state institutions by elites and private interests). The post-crisis process of implementing institutional reforms in Serbia has revealed the most problems in two reform areas: the rule of law and corruption control (indicators are still in the negative zone). Institutional reforms in the other four areas of monitoring stagnated in the period 2015-2018, which indicates that the impact of institutions on transitional economic growth in Serbia is negligible.

\section{Macroeconomic and Economic Balance Sheet of Structural Changes}

\subsection{Macroeconomic Effects}

The global economic situation affected economic growth in all countries in the region in the period 2015-2019. The average rate of economic growth in the last five years in the Republic of Serbia was $3.5 \%$, so that the GDP reached 46 billion. EUR. The new model of economic growth was based on investment growth, with investments growing at an average of $11.5 \%$ per year. Personal consumption (average growth of $2.4 \%$ ) also made a significant contribution to economic growth. Thus, in 2019, the growth of investments of $15.6 \%$ and personal consumption of $3.1 \%$ influenced the total domestic demand to contribute to GDP growth with 5.8 percentage points. In the same period, net exports had a negative contribution.

Certainly, the most important positive macroeconomic effect of the implemented fiscal consolidation is the reduction of internal and external macroeconomic imbalances. $(-0.2 \%$ of GDP). With the reduction of the current account deficit, it is more difficult, in 2019 the deficit increased due to the growth of the foreign trade deficit $(6.9 \%$ of GDP).

Table 5. Macroeconomic Balance 2015-2019. (growth rates in\%).

\begin{tabular}{|c|c|c|c|c|c|}
\hline & 2015 & 2016 & 2017 & 2018 & 2019 \\
\hline GDP & 1.8 & 3.3 & 2.0 & 4.4 & 4.2 \\
\hline Manufacturing & 5.7 & 6.0 & 6.3 & 1.9 & 0.2 \\
\hline Net Earnings & -2.1 & 2.5 & 0.9 & 4.4 & 8.5 \\
\hline Current account of balance of payments (\% of GDP) & -3.5 & -2.9 & -5.2 & -4.8 & -6.9 \\
\hline Fiscal deficit/surplus (\% GDP) & -3.5 & -1.2 & 1.1 & 0.6 & -0.2 \\
\hline Public Debt (\% GDP) & 70.0 & 67.8 & 57.9 & 53.7 & 52.0 \\
\hline Inflation (end of period) & 1.5 & 1.6 & 3.0 & 2.0 & 1.9 \\
\hline
\end{tabular}

Source: Serbian Business Registers Agency, National Bank of Serbia, Ministry of Finance. 
The most important factor that contributed to the external balance is FDI, the average net inflow of FDI in the last five years was 2.6 billion EUR, which relaxed the chronic coverage of the current account deficit.

Balanced public finances and increased fiscal discipline have contributed to the reduction of public debt (from $70 \%$ share of public debt in GDP in 2015 to $52 \%$ at the end of 2019).

The positive macroeconomic effects had the greatest impact on the labor market. The number of employees increased, the unemployment rate decreased (from $17.7 \%$ in 2015 to $10.4 \%$ in 2019), and the average growth of net wages in 2015-2019. was $4.0 \%$.

\subsection{Economic Balance}

The main feature of the economic situation is the trend of key economic and financial performance of the economy of the Republic of Serbia: growth of newly created value, total and operating income, net financial result, capital and employment, as well as reduction of current losses and decline of cumulative loss.

The positive performance of the economy in 2019 is confirmed by year-on-year data:

1. Gross value added of the economy (EUR 20.6 billion) increased by $5.4 \%$ in real terms;

2. The number of employees increased by $2.7 \%$;

3. Positive net financial result (EUR 3.3 billion), but lower than in 2018;

4. Real growth of total income $4.9 \%$;

5. Real capital growth of $0.8 \%$;

6 . Real decline in cumulative loss of $-5.7 \%$;

7. Net profit was realized by 62,517 companies $(59.8 \%)$ in which $83.6 \% \quad(979,872)$ of non-financial sector employees were employed, net loss was reported in 26,649 (25.5\%) companies with 189,573 employees, while $15,321 \quad(14) .7 \%)$ companies with 2,445 employees showed zero financial result.

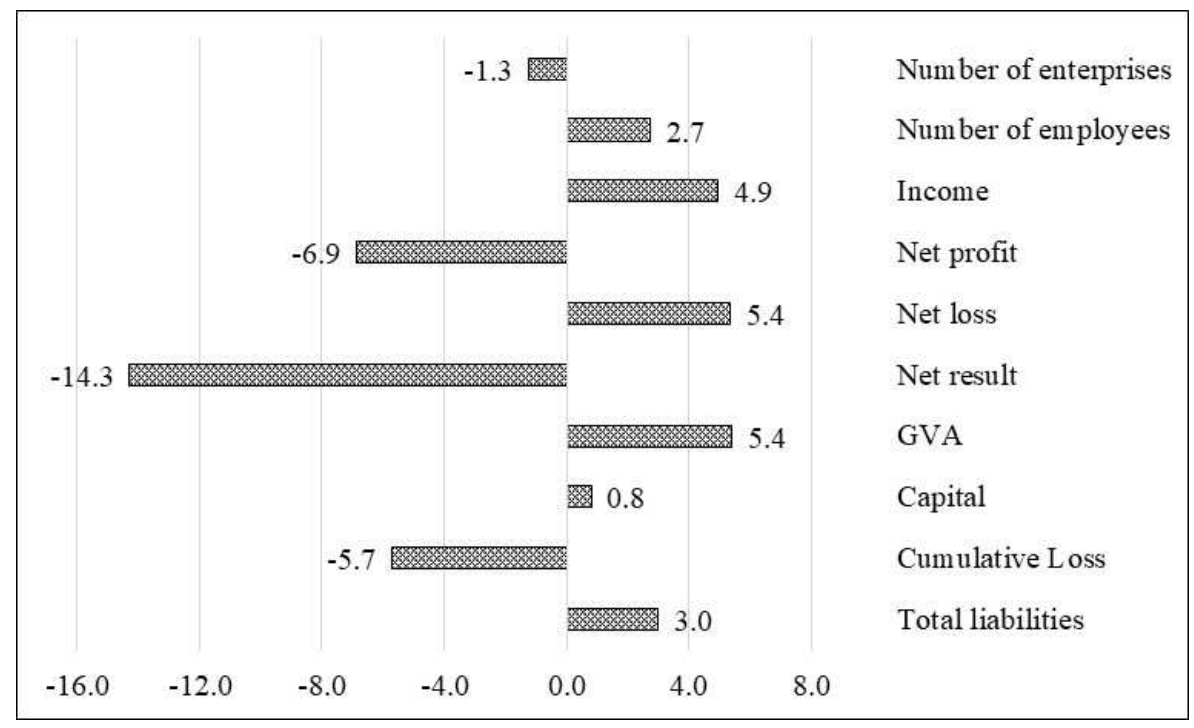

Source: The authors based on the data Serbian Business Registers Agency

Figure 1. Business performance of the economy in 2019/2018. (growth / decline rates).

It should be said that in 2020 , due to the global recession, the overflow of negative effects of COVID-9 and economic recession, there will inevitably be a drop of GDP (projections range from $-2 \%$ to $\%$ of GDP) and the deterioration of economic and financial performance of the economy [15]. Forecast 2021 announcing a return to the dynamic growth path (projections are about $5 \%$ ), but the risks to returning economies to equilibrium remain high $[10,11,17]$.

\section{Structural Analysis of the Economic-Financial Performance of the Republic of Serbia}

\subsection{New Value Structure Changes}

The main characteristic of the conjunctival period is the growth of the newly created value in the economy of the Republic. The real cumulative growth of gross value added (GVA) of the economy in the period 2015/19 it was $35.3 \%$, but the growth was oscillator character, it did not have a straight upward trend, growth indices were the highest in 2016 and 2018. In the structure of the GVA economy, besides the continuation of the trend of strengthening the service sector, the growth of the construction sector was observed, while in the structure of employees, growth of employees in the processing industry and in some services activities (Tourism, Professional, Scientific and Innovative Services and Administrative Services) was observed. The structural decline of the Transport, Agriculture, Forestry and Water, Mining and Electricity Supply sector is evident.

Generally, the participation of the traditional sectors in generating new value is still dominant, but with a mild trend 
of decline, the detriment of expert, Scientific, ICT and Administrative services, which have a mild growth trend.
The growth of new employees is dominant in the manufacturing industry.

Table 6. Structural sectoral changes 2015-2019 GVA and employment (economy=100).

\begin{tabular}{|c|c|c|c|c|c|c|c|}
\hline & \multirow{3}{*}{ Economy } & \multicolumn{6}{|l|}{ GVA } \\
\hline & & \multicolumn{2}{|l|}{2015} & \multirow{2}{*}{$\begin{array}{l}2017 \\
100,0 \\
\end{array}$} & \multirow{2}{*}{$\begin{array}{l}2018 \\
100,0 \\
\end{array}$} & \multirow{2}{*}{$\begin{array}{l}2019 \\
100,0\end{array}$} & \multirow{2}{*}{ 2015-2019 } \\
\hline & & 100.0 & 100,0 & & & & \\
\hline A & Agriculture & 2.9 & 2.9 & 2.4 & 2.4 & 2.2 & -0.7 \\
\hline B & Mining & 4.8 & 3.7 & 4.5 & 4.2 & 3.9 & -0.8 \\
\hline $\mathrm{C}$ & Manufacturing & 28.5 & 28.8 & 28.9 & 28.2 & 27.6 & -0.9 \\
\hline $\mathrm{D}$ & El. energy & 8.2 & 11.1 & 9.7 & 8.5 & 7.7 & -0.5 \\
\hline $\mathrm{E}$ & Water supply & 2.6 & 2.3 & 2.2 & 2.2 & 2.0 & -0.6 \\
\hline G & Trade & 17.6 & 17.4 & 18.1 & 17.0 & 17.9 & 0.4 \\
\hline $\mathrm{H}$ & Traffic & 7.8 & 7.7 & 7.5 & 9.8 & 7.0 & -0.9 \\
\hline I & Accommodation and food & 1.2 & 1.1 & 1.1 & 1.3 & 1.4 & 0.2 \\
\hline $\mathrm{J}$ & ICT & 9.3 & 8.8 & 8.6 & 8.5 & 9.4 & 0.1 \\
\hline K & Finance \& Insurance & 0.2 & 0.1 & 0.1 & 0.1 & 0.2 & 0.0 \\
\hline $\mathrm{L}$ & Real estates & 1.1 & 1.0 & 1.1 & 1.0 & 1.2 & 0.1 \\
\hline M & Professional \& Scientific activities & 4.9 & 4.4 & 4.6 & 5.0 & 5.3 & 0.5 \\
\hline $\mathrm{P}$ & Education & 0.1 & 0.2 & 0.2 & 0.2 & 0.2 & 0.1 \\
\hline Q & Health and social & 0.0 & 0.0 & 0.0 & 0.1 & 0.1 & 0.0 \\
\hline $\mathrm{R}$ & Arts, entertainment, etc. & 0.7 & 0.8 & 0.9 & 1.0 & 1.0 & 0.3 \\
\hline $\mathrm{S}$ & Other services & 0.2 & 0.2 & 0.2 & 0.2 & 0.2 & 0.0 \\
\hline $\mathrm{T}$ & Households & 0.0 & 0.0 & 0.0 & 0.0 & 0.0 & 0.0 \\
\hline
\end{tabular}

Table 6. Continued.

\begin{tabular}{|c|c|c|c|c|c|c|c|}
\hline & \multirow{3}{*}{ Economy } & \multicolumn{6}{|c|}{ Employment } \\
\hline & & 2015 & 2016 & 2017 & 2018 & 2019 & \multirow{2}{*}{ 2015-2019 } \\
\hline & & 100.0 & 100.0 & 100.0 & 100.0 & 100.0 & \\
\hline A & Agriculture & 3.4 & 3.1 & 3.0 & 2.8 & 2.7 & -0.7 \\
\hline B & Mining & 2.2 & 2.0 & 2.0 & 2.0 & 2.0 & -0.2 \\
\hline $\mathrm{C}$ & Manufacturing & 30.8 & 30.8 & 31.8 & 32.2 & 32.5 & 1.7 \\
\hline $\mathrm{D}$ & El. energy & 3.9 & 4.1 & 3.8 & 3.5 & 3.3 & -0.6 \\
\hline $\mathrm{E}$ & Water supply & 3.7 & 3.5 & 3.4 & 3.2 & 3.1 & -0.6 \\
\hline $\mathrm{F}$ & Construction & 6.7 & 6.4 & 6.3 & 6.4 & 6.6 & 0.0 \\
\hline G & Trade & 19.8 & 19.8 & 19.3 & 19.2 & 18.9 & -0.9 \\
\hline $\mathrm{H}$ & Traffic & 9.6 & 9.4 & 9.1 & 8.7 & 8.0 & -1.6 \\
\hline I & Accommodation and food & 2.3 & 2.3 & 2.4 & 2.6 & 2.7 & 0.5 \\
\hline $\mathrm{J}$ & ICT & 4.3 & 4.2 & 4.3 & 4.3 & 4.3 & 0.1 \\
\hline $\mathrm{K}$ & Finance \& Insurance & 0.3 & 0.3 & 0.3 & 0.3 & 0.4 & 0.0 \\
\hline $\mathrm{L}$ & Real estates & 0.4 & 0.4 & 0.4 & 0.4 & 0.5 & 0.0 \\
\hline M & Professional \& Scientific activities & 5.3 & 5.4 & 5.5 & 5.5 & 5.6 & 0.4 \\
\hline $\mathrm{N}$ & Administrative activities & 5.3 & 5.9 & 6.3 & 6.7 & 7.1 & 1.8 \\
\hline $\mathrm{O}$ & State administration, etc. & 0.0 & 0.0 & 0.0 & 0.0 & 0.0 & 0.0 \\
\hline$P$ & Education & 0.3 & 0.4 & 0.4 & 0.4 & 0.5 & 0.1 \\
\hline Q & Health and social & 0.3 & 0.2 & 0.2 & 0.2 & 0.2 & -0.1 \\
\hline $\mathrm{R}$ & Arts, entertainment, etc. & 1.1 & 1.1 & 1.1 & 1.1 & 1.1 & 0.0 \\
\hline S & Other services & 0.4 & 0.5 & 0.5 & 0.4 & 0.4 & 0.0 \\
\hline $\mathrm{T}$ & Households & 0.0 & 0.0 & 0.0 & 0.0 & 0.0 & 0.0 \\
\hline
\end{tabular}

Source: Authors based on Serbian Business Registers Agency data.

\subsection{Sectoral Changes in Profitability}

Sectoral amplitudes of profitability are a reflection of sectoral amplitudes in the structure of total and operating profit of the economy. The trade has consistently had high business profitability. The processing industry is in the period 2016-2019. aged high rates of return on equity, ie business profitability. The construction industry has been constantly improving the performance of both overall and business profitability from year to year, but still below the economy average. The Electricity, Agriculture and Water Supply sectors operated in a zone of low profitability and negative financial leverage. The Transport sector showed volatility, especially in 2019 (decline in total from $7.3 \%$ to $2.8 \%$ and business profitability from $12.9 \%$ to $5.3 \%$ ). 


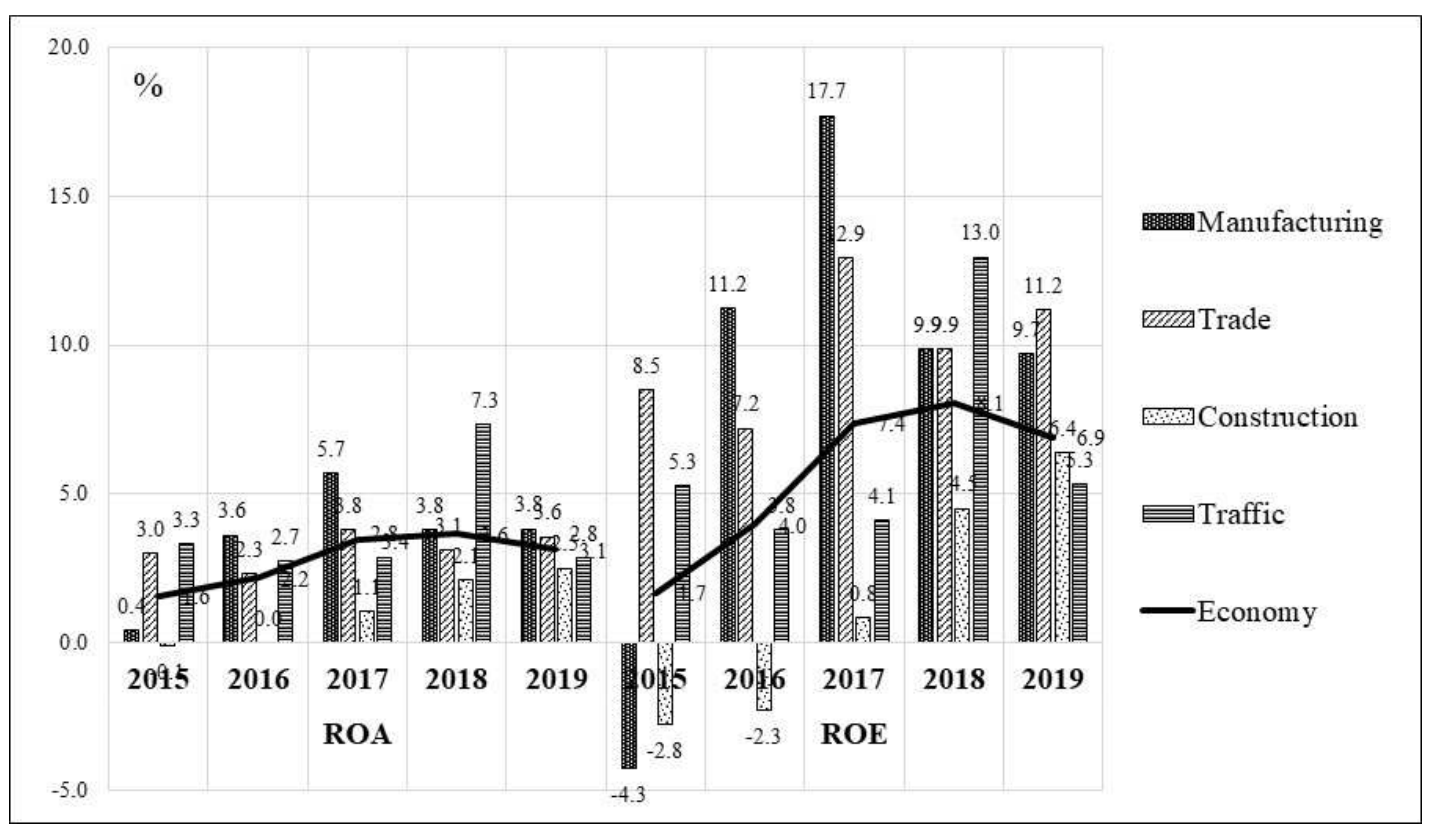

Source: Authors based on SBRA data. Note: ROA (Return on Assets) - rate of return on business assets; ROE (Return on Equity) - rate of return on equity.

Figure 2. Sectoral changes in profitability 2015-2019: ROA and ROE.

\subsection{Structural Changes in the Economy: Large Enterprises and the SMEs Sector}

The stability of operations over the last five years has affected the basic performance of large companies. The total number of large enterprises increased by $4 \%$ (from 548 to 570 ), employment increased by $3 \%$ and total income by
$2.1 \%$, while at the same time the cumulative loss decreased by $20 \%$. The business of large companies was primarily influenced by the business of two large companies "HBIS GROUP Serbia Iron \& Steeld. o. o. Belgrade" and "Serbia Zijin Bor Copper" in 2018. The decrease in total capital of $3 \%$ was influenced by reductions in the value of capital at the companies "Vansierports" (Vinci Airports) and "AlDahre".

Table 7. Business performance of large companies and the MSME sector in 2018 and 2019.

\begin{tabular}{|c|c|c|c|c|c|c|c|c|c|c|c|c|c|}
\hline & \multirow{2}{*}{$\begin{array}{l}\text { Companies } \\
\text { No. }\end{array}$} & \multirow{2}{*}{$\begin{array}{l}\text { Employees } \\
\text { No. }\end{array}$} & \multicolumn{11}{|c|}{ 2019. (EUR million) } \\
\hline & & & \multicolumn{2}{|c|}{ Income } & \multicolumn{2}{|c|}{ Net Income } & \multicolumn{2}{|c|}{ Net Loss } & Net Result & GVA & Capital & Cumulated Loss & Total Debt \\
\hline SMEs & 103,917 & 668,632 & 63,06 & & 3,83 & & 1,7 & & 2,100 & 10,926 & 32,088 & 20,958 & 55,262 \\
\hline \multirow[t]{3}{*}{ Large Enterprises } & 570 & 503,258 & 39,86 & & 1,97 & & 744 & & 1,227 & 9,676 & 31,682 & 8,738 & 26,811 \\
\hline & \multicolumn{13}{|c|}{$2019 / 2018$ (rates in \%) } \\
\hline & Companies $\mathbf{N}$ & . Employe & No. & Inc & ome & Net Ince & me & Net Loss & Net Result & GVA & Capital & Cumulated Loss & Total Debt \\
\hline Total & -1.3 & 2.7 & & 4.9 & & -6.9 & & 5.4 & -14.3 & 5.4 & 0.8 & -5.7 & 3.0 \\
\hline SMEs & -1.3 & 2.5 & & 6.8 & & 17.9 & & 11.0 & 24.2 & 11.7 & 4.9 & 1.6 & 2.5 \\
\hline Large Enterprises & 4.0 & 3.0 & & 2.1 & & -33.9 & & -5.8 & -44.0 & -0.9 & -3.0 & -19.6 & 4.0 \\
\hline
\end{tabular}

The business sector (SME) is slowly becoming stronger and more resilient. Particularly positive results in 2019 for medium-sized companies in all segments: growth in the number of companies and employment, positive financial results, growth in GVA and capital and a decrease in total liabilities.

Basic economic and financial performance of the SME sector:

1. In the structure of the MSME sector, there was an increase in the number of medium $(4.6 \%)$ and small $(2.1 \%)$ enterprises, a decrease in the number of micro enterprises $(-1.9 \%)$;

2. Employment growth in medium-sized (4.0\%) and small enterprises $(2.6 \%)$, while the same number of employees was retained in micro-enterprises;

3. Revenue growth in the entire MSME sector (on average $7.2 \%$, small $5.2 \%$ and micro $8.4 \%$ );

4. Positive net result was registered by medium $(7.7 \%)$ and small enterprises $(47.9 \%)$, but micro, due to large losses $(-17.9 \%)$ registered a negative financial result ($38.8 \%$;

5. GVA growth is even in all segments of MSMEs, growth of $11.7 \%$;

6. Capital decreased in micro $(-6.6 \%)$, but increased in small (15.4\%) and medium (8.6\%);

7. Cumulative loss was reduced by small enterprises ($16.7 \%$ ), medium-sized enterprises registered small growth $(1.7 \%)$, while growth in micro-enterprises was $6.3 \%$; 
8. In the structure of liabilities of the SME sector, liabilities decreased in medium-sized companies ($0.8 \%$ ), in small enterprises they are at the same level, but in micro-enterprises a growth of liabilities of $5.4 \%$ was registered.

\subsection{Changes in the Ownership Structure of the Economy}

Dynamic inflow of FDI and strengthening the influence of companies with majority foreign capital on the business of the economy in the period 2015-2015. influenced changes in the ownership structure of the economy. The research results show that foreign companies have better business performance, not only than the average domestic firm at the time of acquisition, but also improve their performance after purchase faster than domestic firms [10]. Foreign private companies are constantly increasing their contribution to economic growth, increasing employment by more than 50\%, and their income, GVA and capital have grown above average. In the same period, domestic private companies improved their performance (increased net profit and reduced net losses). State-owned companies reduced the number of employees by $20 \%$, as well as losses and liabilities, but they also operated at a loss. The share of majority foreign-owned companies in GDP is constantly increasing, from $12.3 \%$ in 2015 to $15.9 \%$ in 2019 . The share of domestic private companies in GDP increased from $17.5 \%$ to $21.4 \%$, while at the same time the share of state-owned enterprises fell from $8.3 \%$ to $7.3 \%$. Growth in the number of foreign private companies in the period 2015-2019. was $8.1 \%$; an increase in the number of employees in the economy of $18.3 \%$ is mostly located in foreign companies (growth of 53.1\%), which today employs about 300,000 workers.

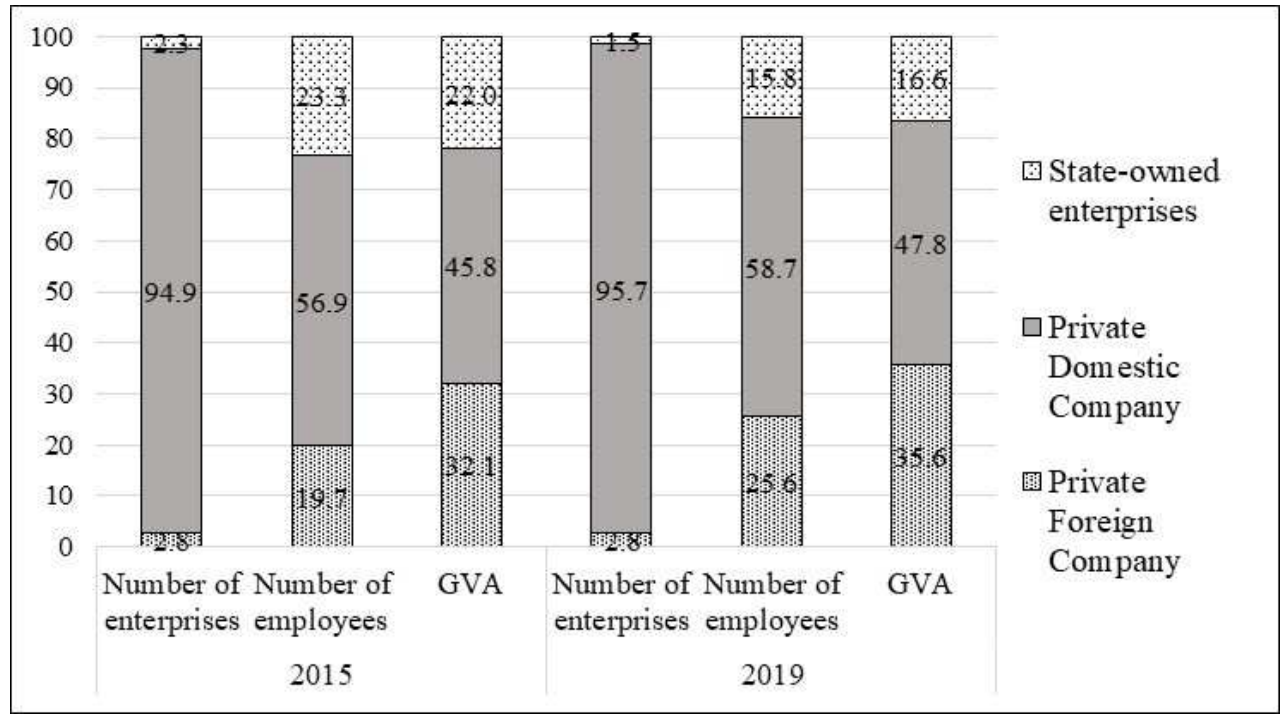

Source: Authors based on the data SBRA

Figure 3. Changes in the ownership structure of the economy 2015-2019.

Foreign private companies have increased the newly created value by $50 \%$, significantly higher than the domestic private sector $(41.1 \%)$; they increased capital twice the growth of capital in the domestic private sector $(55 \%$ versus $27.8 \%$ ). The most dynamic structural shifts were in the employment segment and the BDV in foreign private companies: the participation of foreign companies in the structure of employees has increased by 6 percentage points, and in the structure of the BDV for 3.5 p.p. At the same time, the participation of state enterprises in the number of 0.8 p.p. (from $2.3 \%$ to $1.5 \%$ ), employment for 7.5 p.p. (from $23.3 \%$ to $15.8 \%$ ) and in BDV for 5.4 p.p. (from $22 \%$ to $16.6 \%$ ).

\section{Conclusion}

Economic and financial performance of the economy in the period of conjunction 2015/2019 are significantly improved. The average economic growth in Serbia of 3.5\% was higher than the average growth in the countries of the region. A key contribution to economic growth was made by investments, and in a somewhat smaller volume also the growth of personal consumption $[12,13]$. Structural changes, as a rule, have a positive impact on basic macroeconomic results and productivity growth [4]. Effects of the implemented fiscal consolidation in the Serbian economy have contributed continuously, year after year, to the improvement of the macroeconomic and economic balance of the economy, although it should be noted that 2019. there are signals slowing the trend. The fiscal deficit has been since 2017. it was balanced, but the current balance deficit is still acute. The trend of balanced public finances and the reduction of public and foreign debt has been damaged in 2020. due to the pandemic caused by COVID-19 in all transition countries [1].

Due to the huge transitional backlog and peripheral economic status of the entire area of the SEE, and in addition to the global conjunction, the implemented structural reforms did not take place with the desirable dynamics, especially in the segment of 
solving the problems of large state losses and economicfinancial restructuring of public enterprises at all levels [9].

Although the enterprise sector has improved its performance, the resistance of medium enterprises is particularly increased, institutional problems affecting business environment are still pronounced. Structural analysis of the economy has shown a continuation of the trend of strengthening the GDV service sector, a mild revitalization of the construction and employment sector in the processing industry. Also, the profitability of the Trade, Manufacturing and Construction sectors has improved.

The analysis of structural performance of the property structure shows the trend of strengthening the influence of foreign companies on business operations of the economy, as well as that multinational enterprises have better business performance than domestic private companies. Qualitative performance of the business of foreign private companies is at a higher level than the performance of the domestic private sector. Structural reform activities in the coming period should primarily focus on creating the most stimulating environment for the development of domestic enterprises and growth of capital investments. On the other hand, it is necessary to improve the efficiency of management of state property and speed up the problem of major state and public losses. The stimulating policy of the state to focus on the construction of enterprise infrastructure, strengthening startup mechanisms [8], the formation of sectoral industrial zones, dismantling of companies from administrative and financial burden, defining incentive packages to economic entities and economic sectors with the aim improving energy efficiency, the monitoring of clean technologies and environmental standards.

\section{References}

[1] Agnello, L., Castro, V., Jalles, J. T. \& Sousa, R. M. (2015). What Determines the Likelihood of Structural Reforms. European Journal of Political Economy, 37, 129-145. doi: 10.1016/j.ejpoleco.2014.10.007.

[2] European Bank for Reconstruction and Development. (2020). Transition report 2019-2020.

[3] European Commission-General Directorate for Economic and Financial Affairs. (2020). European Economic Forecast Spring 2020, Summer 2020 (Interim). Institutional Paper 132. doi: $10.2765 / 828014$.
[4] Foster-Mcgregor, N. \& Verspagen, B. (2016). The Role of Structural Change in the Economic Development of Asian Economies. Asian Development Review, 33 (2), 74-93. doi: 10.1162/ADEV_a_00073.

[5] Guerrieri, V., Lorenzoni, G., Straub, L., \& Werning, I. (2020). Macroeconomic Implications of COVID- 19: Can Negative Supply Shocks Cause Demand Shortages? NBER Working Paper Series, No 26918. National Bureau of Economic Research.

[6] IMF. (2015). Structural Reforms and Macroeconomic Performance - Initial Considerations for the Fund. doi: PP4995.

[7] IMF. (2020). External Sector Report: Global Imbalances and the COVID-19 Crisis. Washington, DC.

[8] Jakopin, E., Cokorilo, N., Nikolic, S., Miloševic, S., Trajkovic, M., Djuric, S. (2018). Start-up in Serbia 2017 trends and structural analysis. Belgrade. Ministry of economy.

[9] Jakopin, E., \& Cokorilo, N. (2019). Business analysis of public and state enterprises in Serbia 2015-2017. Trends, special edition. RSO. Belgrade.

[10] Megginson, W. and Fotak, V. (2020). Government Equity Investments in Coronavirus Bailouts: Why, How, When? Government Equity Investments in Coronavirus Bailouts: Why, How, When? by William L. Megginson, Veljko Fotak: SSRN.

[11] Miles, D., and Scott, A. (2020). Will Inflation Make a Comeback after the Crisis Ends? VoxEU.org, CEPR Policy Portal. https://voxeu.org/article/willinflation-make-comebackafter-crisis-ends

[12] Ragoussis, A. (2020). How Beneficial Are Foreign Acquisitions of Firms in Developing Countries? In Global Investment Competitiveness Report 2019/2020. World Bank. doi: 10.1596/978-1-4648-1536-2.

[13] Smith-Bingham, R., Wittenberg, A. and Kaniewski, D. (2020). Building national resilience: Aligning mindsets, capabilities and investments". Marsh \& McLennan Advantage.

[14] World Economic Forum (WEF). (2020). The Global Competitiveness Report 2019.

[15] World Bank. (2020a). COVID-19 Crisis through a Migration Lens. Migration and Development. Brief 32, Washington, DC.

[16] World Bank. (2020b). Doing Business Report 2020. Washington, DC.

[17] WTO. (2020). World Trade Report 2020: Innovation and industrial policies in the digital age. Geneva. 